\title{
PERAN MAKNA DALAM PENERJEMAHAN
}

\author{
Abdul Wahab Rosyidi
}

Dosen Jurusan Bahasa dan Sastra Arab,

Fakultas Humaniora dan Budaya, Universitas Islam Negeri (UIN) Malang.

Jalan Gajayana No. 50 Telepon (0341) 570872, Faksimile (0341) 570872 Malang 65144.

Ketua Unit Litbang Dimas Fak. Humaniora dan Budaya UIN Malang

E-Mail: <aw_rosyidi@yahoo.co.id>

\begin{abstract}
Basically translating is not merely transferring meaning behind the words or sentences in a source language into a target language, but also considering many things to identify the real meaning such as, situational, linguistic, and cultural contexts.We should take into account some principles regarding the word meaning, that is, 1) meaning is changeable due to the time change, and the change is not an absolute requirement for any word; 2) a word in a language with different dialects may have different meanings, it is due to the meaning extension and reduction; 3 ) a word does not refer to the thing it refers to, but it is only a symbol; and 4) a word often has more than one meaning. Therefore, meaning has an important role in a process of translation from a source language into the a target language. For that reason, a translator has to consider which component of meaning accuracy is in line with the meaning in the source language to be translated into the target language.
\end{abstract}

\section{Keywords}

Meaning, Word, Change of Meaning, Translating 


\section{Pendahuluan}

Geliat terjemahan buku-buku asing ke dalam bahasa Indonesia semakin mengelora dan semakin menunjukkan nafas kehidupan dalam dunia perbukuan Indonesia. Arus informasi yang begitu terbuka membawa kemungkinan pertukaran informasi, pengetahuan, dan budaya yang sangat luar biasa antar semua negara. Dan terjemahan ternyata memiliki fungsi sebagai sarana yang luar biasa.

Dengan penerjemahan, terjadi dinamisasi kemajuan dan perkembangan ilmu pengetahuan, wawasan dan budaya, karena terjemahan memungkinkan mereka yang tidak berbahasa asing mengakses ilmu pengetahuan. Terjemahan juga yang menjadikan kisah orang lain menjadi kisah kita sendiri, kita dapat merasakan karakternya dan memilikinya secara keseluruhan. Terjemahan pula yang membawa zaman keemasan bagi Islam, sehingga umat Islam bisa mengembangkan peradaban yang gilang-gemilang beberapa abad yang lalu.

Di tengah-tengah urgensi kegiatan penerjemahan tersebut, ternyata terdapat banyak buku terjemahan yang saat dibaca, terkesan sukar baik bahasa maupun isinya. Bukan karena bahasanya yang tinggi sehingga pembaca kesulitan memahami dan tidak dapat menikmati ketika membaca, akan tetapi juga karena isi dan makna yang sudah banyak terdistorsi. Meskipun gaya dan pendekatan yang digunakan oleh para penterjemah tidak sama satu dengan lainnya, perlu kiranya penterjemah memperhatikan pada salah satu standart penerjemahan yaitu unsur ketepatan (accuracy). Ketepatan mengacu pada tepat atau melencengnya makna teks asli (bahasa sumber) saat menterjemahkan ke bahasa target (bahasa sasaran). Unsur ini merupakan syarat utama karya terjemahan yang terterima di masyarakat. Bila karya terjemahan sudah tidak dapat membawa makna orisinal sebuah karya, maka karya terjemahan yang demikian akan mendistorsi makna yang ingin disampaikan oleh penulis asli.

Oleh karena itu kegiatan menterjemah merupakan hal yang sangat urgen, sedangkan kegiatan tersebut tidak mudah untuk dilakukan oleh setiap orang, hal itu disebabkan karena menterjamah 
pada hakekatnya adalah tidak sekedar mentransfer makna dibalik kata/kalimat dalam bahasa sumber ke dalam bahasa sasaran, akan tetapi ada banyak hal yang juga harus memperoleh perhatian untuk menemukan makna yang sesungguhnya, seperti halnya konteks dalam situasi (siyaqAl-hal), konteks linguistik (siyaqAl-luhawi) dan konteks kultural (siyaq tsaqofi).

Membahas tentang makna perannya sesungguhnya sangat menarik apabila menggunakan pendekatan filsafat tafsir atau hermeneutika baik yang klasik maupun yang moderen. Akan tetapi dalam hal ini kita akan menggunakan pendekatan linguistik, karena di dalam linguistik itu sendiri telah muncul sebuah ilmu pengetahuan yang secara khusus membicarakan makna/arti, yakni semantik.

\section{Pengertian Menerjemah}

Secara sederhana menerjemah adalah usaha-usaha untuk mengubah suatu bentuk bahasa sumber ke dalam bahasa lain (bahasa sasaran) dengan tetap memperhatikan aspek kesepadanan semua unsur yang ada di dalamnya, yakni frasa, klausa, paragraf, dan lain-lain, baik secara lisan maupun tulisan.

Ada berbagai macam definisi tentang hakekat terjemah, Nida (1969:36) misalnya, ia mendefinisikan terjemah sebagai usaha mengalihkan pesan yang ada dalam suatu bahasa kedalam bahasa lain, sedemikian rupa sehingga orang yang membaca atau mendengarkan pesan yang telah dialihkan kedalam bahasa sasaran, memperoleh kesan yang sama dengan kesan yang diterima orang yang membaca atau mendengar pesan tersebut dalam bahasa sumber.

Sedangkan Larson memberikan definisi lain. Menurutnya menterjemah berarti: 1) Mempelajari leksikon, struktur gramatikal, situasi komunikasi dan konteks bahasa sumber. 2) Menganalisis teks bahasa sumber untuk menemukan maknanya. 3) Mengungkapkan kembali makna yang sama dengan menggunakan leksikon dan struktur gramatikal yang sesuai dengan bahasa sasaran dan konteks budayanya. 
Selain itu, masih banyak definisi tentang terjemah dan masingmasing menitikberatkan pada sudut pandangnya. Yang jelas, menterjamah adalah kegiatan mengalihkan pemikiran-pemikiran konseptual yang ditulis oleh penulis bahasa sumber ke dalam bahasa sasaran. Dalam tataran bahasa, sebuah terjemahan pada umumnya dibagi menjadi dua, yaitu:

Pertama, Terjemah Terikat ( rank-bound translation) adalah jenis terjemah yang terbatas secara lebih khusus dalam penerjemahan pada tataran kata dan morfem saja, yakni pengantian kosakata dan morfem bahasa sasaran. Pada jenis penerjemahan ini biasanya tidak terjadi penerjemahan pada tataran yang lebih tinggi daripada tataran kata dan morfem. Di antara jenis terjemahan ini adalah terjemahan kata per kata (word for word tranlation)

Kedua, Terjemahan Bebas ( unbounded translation) adalah jenis terjemah tuntas yang tidak dibatasi oleh keterikatan pada penerjemahan suatu tataran tertentu. Jenis terjemahan ini selalu berada pada tataran yang lebih tingi dari pada tataran kata dan morfem, bahkan lebih luas dari pada kalimat.

\section{Tingkat Abstraksi Bahasa}

Untuk mempermudah mengenali dan memperoleh makna dari suatu kata, perlu mengenal tingkat abstraksi sebuah bahasa. Selain berbeda-beda fungsinya, bahasa dan ujaran juga berbeda tingkat abstraksinya (abstraction levels of language and speech), dari tingkat yang kongkrit sampai pada tingkat yang sangat abstrak.

Menurut Yusuf Suhendra (1994:96), abstraksi adalah proses pemilihan aspek-aspek kenyataan yang membedakannya dari kenyataan yang lain ketika kita berbahasa. Ketika kita mengucapkan sebuah kata, kita sebenarnya sedang membuat sebuah kategorisasi yang hanya dapat mengungkapkan sebagian saja dari sifat-sifat atau kenyataan yang ada. Semakin tinggi tingkat abstraksi sebuah kata semakin sukar kata itu dikaitkan dengan kenyataan dan semakin luas 
makna kata itu. keluasan makna itu tidak saja dapat membuat kita sukar menafsirkan, melainkan juga menjadikan makna itu kabur.

Menurut Alfred Korzybsky (Suhendra, 1994:97), salah seorang tokoh terkemuka dari aliran semantik umum, bahwa tingkat abstraksi kata itu bisa dibagi menjadi beberapa tingkatan, yaitu:

Pertama, Tingkat Peristiwa (event level), yakni tingkat abstraksi bahasa yang ada di alam semesta raya. Tingkat abstraksi ini tidak dapat dirasakan secara langsung oleh panca indera kita tetapi keberadaannya serta sifat-sifatnya dapat kita ketahui dari hasil penelitian yang dikemukakan oleh para ilmuwan. Tingkat peristiwa ini merupakan tingkat abstraksi tertinggi yang menghasilkan peristiwa di luar bahasa.

Kedua, Tingkat Objek (object level), yakni tingkat abstraksi tentang segala sesuatu yang dapat dijangkau oleh panca indera manusia.

Ketiga, Tingkat Verbal Pertama, yakni tingkat penamaan dan pernyataan deskriptif. Misalnya kita menyentuh benda yang menyengat tangan kita, maka kita sepakat menamainya dengan panas, begitu juga sebaliknya apabila benda itu menyebabkan tangan kita beku, maka gejala itu kita beri simbol dingin.

Keempat, Tingkat Verbal Kedua, yakni tingkat penjelasan istilahistilah dan pernyataan-pernyataan inferensial atau pernyataanpernyataan dugaan dan kesimpulan sementara, yaitu pernyataan yang melebihi fakta nyata dari situasi tertentu.

Kelima, Tingkat Verbal Ketiga, yakni tingkat tentang sesuatu pernyataan yang didasarkan pada pernyataan lainnya yang merupakan persepsi terhadap sesuatu.

\section{Pengertian Makna}

Dalam kehidupan sehari-hari, kata makna digunakan dalam berbagai bidang maupun dalam konteks yang berbeda-beda. Kata makna biasanya sering disejajarkan dengan beberapa kosakata seperti arti, gagasan, konsep, pernyataan, pesan, maksud, firasat, dan isi. Dari 
sekian kata yang disebutkan, kata arti yang punya pengertian paling dekat dengan makna (Kridalaksana, 1982;15). Namun demikian dua kata ini tidak berarti sinonim mutlak.

Sedangkan kata makna sebagai istilah, mengacu pada pengertian yang sangat luas. Dari sekian banyak pengertian, ada sebuah pengertian tentang makna yang dikemukakan oleh Grice dan Bolinger (Aminuddin, 2003:83), bahwa makna adalah hubungan antara bahasa dengan dunia luar yang telah disepakati bersama oleh para pemakai bahasa, sehingga bisa saling dimengerti. Dari pengertian ini ada tiga unsur penting yang dimiliki makna, yaitu: 1) Makna adalah hubungan antara bahasa dengan dunia luar. 2) Makna adalah kesepakatan pengguna bahasa. 3) Perwujudan makna dapat digunakan untuk menyampaikan informasi sehingga dapat saling dimengerti.

Untuk lebih jelas, ada tiga pendekatan yang bisa digunakan untuk memahami pengertian makna, yaitu: 1) pendekatan referensial, 2) pendekatan ideasional, 3) pendekatan behavioral.

Menurut Aminuddin (2003:55), dalam pendekatan referensial, makna diartikan sebagai label yang berada dalam kesadaran manusia untuk menunjuk dunia luar. Sebagai label atau julukan, makna itu hadir karena adanya kesadaran pengamatan terhadap fakta dan penarikan kesimpulan yang keseluruhanya berlangsung secara subjektif. Terdapatnya julukan simbolik dalam kesadaran individual itu, lebih lanjut memungkinkan manusia untuk menyusun dan mengembangkan skema konsep. Kata pohon misalnya, berdasarkan kesadaran pengamatan dan penarikan kesimpulan, bukan hanya menunjuk pada jenis tumbuh-tumbuhan, melainkan memperoleh julukan sebagai ciptaan, hidup, fana.

Menurut Aminuddin (2003:55), dalam pendekatan ideasional, makna adalah gambaran gagasan dari suatu bentuk kebahasaan yang bersifat sewenang-wenang, tetapi memiliki konvensi sehingga dapat saling dimengerti.

Dalam dua pendekatan tersebut di atas dapat diketahui bahwa, pertama, pendekatan referensial dalam mengkaji makna lebih 
menekankan pada fakta sebagai objek kesadaran pengamatan dan penarikan kesimpulan secara individual, dan kedua, pendekatan ideasional lebih menekankan pada keberadaan bahasa sebagai media dalam mengolah pesan dan menyampaikan informasi. Oleh karena itu pendekatan behavioral merasa keberatan dengan kedua pendekatan tersebut, dan berpendapat bahwa konteks sosial dan situasional dianggap mempuyai peran penting dalam melahirkan makna.

\section{Makna Kata}

Salah satu cabang linguistik yang memperbincangkan tentang makna/arti adalah semantik (ma'ani/dalalah). Para ahli linguis (bahasa) tidak terdapat kesepakatan kapan sesungguhnya manusia mulai memperbicangkan persoalan makna secara ilmiah. Kesepakatan yang ada adalah istilah makna itu persoalan yang membingungkan. Apa sesungguhnya makna itu? Bagaimana memperoleh makna? Dan siapa yang berhak untuk memberikan makna? Terkait dengan hal tersebut, ada beberapa prinsip yang harus diperhatikan berkenaan dengan pemberian makna kata sebagaimana diungkapkan oleh Ali Al-Khouli (1982:93):

Pertama, Makna kata itu bisa mengalami perubahan sejalan dengan perubahan waktu dan perubahan ini bukan persyaratan mutlak yang diperlakukan untuk setiap kata.

Kedua, Satu kata dalam satu bahasa yang dialeknya berbeda kadang-kadang juga memberikan makna yang berbeda dan perbedaan ini sifatnya tidak substantif. Perbedaan ini mungkin terjadi karena perluasan atau penyempitan makna.

Ketiga, Kata bukanlah sesuatu yang menunjuk pada sesuatu itu, akan tetapi ia hanya merupakan simbol dari sesuatu itu. Kata pintu bukanlah pintu akan tetapi simbol bunyi dari benda yang ditunjuk.

Keempat, Kadang-kadang satu kata bisa memliki makna lebih dari satu.

Kelima, Makna kata kadang-kadang bisa berubah karena perubahan konteks bahasa. 
Dengan demikian apa yang dikatakan oleh Al-Khouli perlu menjadikan pertimbangan ketika kita ingin melakukan pemberian makna atau menterjemahkan sebuah kata atau ungkapan, sehingga proses transfer makna dari bahasa sumber ke dalam bahasa sasaran tidak mengalami distorsi yang berlebihan.

\section{Makna dan Referensi}

Hubungan penamaan antara satu kata dan benda acuannya paling jelas tampak pada nama diri. Di sini ada hubungan satu lawan satu antara nama dan benda. Misalnya nama $K a^{\prime} b a h$ mengacu pada obyek yang ada di Timur Tengah yang menjadi kiblat kaum muslimin, nama Susilo Bambang Yudhoyono mengacu pada pribadi yang memimpin Indonesia. Hubungan antara kata dan benda itu disebut hubungan acuan/referensi. Pandangan ekstensionalisme menyamakan masalah makna dengan acuan (Wahab, 1995:10). Makna satu kata dapat dijelaskan dalam batas-batas hubungan antara kata dan benda yang diacunya. Adapun studi tentang hubungan antara simbol bahasa dan makna yang terkandung di dalamnya, pertama kali dilakukan oleh I.A Richard dan C.K. Ogden tahun 1923 yang terkenal dengan semantic Triangel atau Theory of Meaning yang mengambarkan hubungan keterpautan antara simbol, obyek rujukan, dan gagasan atau mental image dari obyek rujukan dan simbol tersebut (Suhendra, 1994:89).

Sebagaimana di atas, seperti nama diri mengacu pada pribadi yang diacunya, kata benda umum mengacu pada serangkaian bendabenda, kata kerja mengacu pada suatu tindakan, kata sifat mengacu pada keadaan benda atau pribadi, dan kata keterangan mengaju pada keadaan suatu tindakan. Namun tidak selamanya paradigma acuan ini tidak mengalami masalah acuan, referensi. Misalnya, kata dan, tidak, apakah dan semua preposisi sesungguhnya tidak bisa dibuktikan hubungannya (acuan) dengan benda. Oleh karenanya, makna dan referensi juga belum mampu memecahkan penjelasan masalah hakekat makna kata, maka kehadiran teori imajinasi tentang makna dan teori makna 
dan konsep sangat diperlukan untuk memperoleh penjelasan yang komperhenship tentang makna kata.

Teori imajinasi tentang makna menjelaskan bahwa makna kata dalam batas-batas imaji yang ada pada otak (Sapir, 1921:13) penutur (atau pendengarnya). Masalahnya disini ialah bagaimana mengetahui bentuk apa yang diambil oleh imaji itu, maksudnya adalah bahwa imaji itu tidak dapat dilihat, disamping itu juga tak ada imaji yang sama yang berlaku untuk satu benda, boleh jadi seseorang mungkin saja memiliki lebih dari satu imaji untuk ungkapan tunggal seperti imaji tentang segitiga.

Keberatan utama terhadap bentuk ekstrim pandangan imaji menyatakan bahwa imaji itu tidak visual. Seperti Sapir (1921:21), perlu dipertimbangkan misalnya ungkapan tentang unsur tuturan segitiga adalah lambang, bukan persepsi tunggal, bukan juga bayangan terhadap benda tertentu, melainkan suatu konsep, dengan kata lain bayangan terhadap sebungkus pikiran yang meliputi beribu-ribu pengalaman yang berbeda-beda yang siap untuk ditambah dengan ribuan lagi.

\section{Makna Denotatif dan Konotatif}

Bahasa adalah kumpulan kata, satu kata dalam bahasa mengacu sekurang-kurangnya satu makna. Dalam menelaah makna kata, biasanya dibedakan makna denotatif dan makna konotatif.

Makna denotatif adalah makna kamus, makna yang bersifat umum, objektif dan belum ditumpangi oleh isi, nilai, atau rasa tertentu atau referensi pada sesuatu yang ekstralingual menurut makna kata yang bersangkutan. Sebaliknya, makna konotatif adalah bersifat subyektif, dalam pengertian bahwa ada makna lain dibalik makna umum atau makna denotatif. Oleh karena kemandirian dan subyektivitasnya, maka setiap orang akan memandang lain terhadap satu kata atau kelompok kata tertentu (Suhendra, 1994:93).

Dalam kehidupan bermasyarakat, kita sering menjumpai katakata konotatif sering dipergunakan sebagai upaya untuk tidak merusak 
rasa dan intuisi kebahasaan kita. Sebagai contoh, kita tidak terbiasa menggunakan kata mati dalam kalimat pak Amir mati tertabrak mobil, kata "mati" biasanya diperhalus dengan kata-kata meninggal dunia, wafat, berpulang kerohmatullah, contoh lain seperti denotatif kata penjara adalah kemampuan kata tersebut untuk berreferensi pada sebuah penjara, sedang konotasi dari kata tersebut adalah negatif untuk hampir semua penutur, karena alasan yang jelas penghuni penjara sudah tidak punya kebebasan lagi untuk hidup menurut kehendaknya. Intuisi kebahasaan kita akan menjadi rusak apabila kita hanya menggunakan kata-kata yang bersifat denotatif, untuk kepentingan itulah maka kehadiran makna konotatif mutlak diperlukan dalam perbendaharaan linguistik.

\section{Makna Gramatikal dan Makna Leksikal}

Dalam azas-azas linguistik umum J.W.M. Verhaar (2001:386) menyebutan bahwa dalam keseluruhan sistematik bahasa, semantik memainkan peran yang agak berbeda-beda, menurut tataran sistematisnya. Secara negatif fonetik -bunyi bahasa menurut pelafalan dan sifat-sifatnya- tidak berperan secara semantis artinya tidak serta merta bisa menentukan makna, begitu juga dengan fonologi -bunyi bahasa menurut fungsinya- fonem-fonem itu jelas tidak membawa makna/arti, namun mempuyai peran sebagai pembeda makna. Adapun unsur pembawa makna terkecil yang bersifat gramatikal -sistematika bahasa- adalah morfem -satuan minimal gramatikal, dalam hal ini morfem terikat artinya yang tidak bisa berdiri sendiri. Disamping morfem, dalam sistem bahasa (Sintaks, Morfem, Fonem, dan Leksem) sintaks yang berupa fungsi dan kategori merupakan unsur pembawa makna terbesar dalam memberikan makna suatu teks.

Sedangkan semantik leksikal adalah makna yang terkait dengan perkamusan, artinya makna yang diberikan oleh kamus yang diawali dengan bentuk pangkal (pradasar) kata yang bersangkutan. Selain bentuk pradasar ada juga yang menggunakan bentuk akar, seperti bentuk trikonsonantal Arab. 


\section{Makna Kata dan Makna Istilah}

Setiap kata memiki makna. Dalam tataran penggunaan kata itu, baru memiliki makna yang jelas setelah memiliki atau diletekkan dalam konteks tertentu. Makna kata masih bersifat umum, kasar, dan belum jelas. Berbeda dengan makna istilah, makna ini memiliki makna yang pasti, yang jelas dan tidak meragukan meskipun tanpa konteks kalimat.

\section{Makna Idiom dan Pribahasa}

Idiom adalah satuan ujaran yang maknanya tidak bisa diramalkan dari makna unsur-unsurnya, baik secara leksikal ataupun gramatikal. Idiom biasanya dibedakan menjadi dua, idiom penuh dan idiom sebagian. Idiom penuh adalah idiom yang unsur-unsurnya sudah melebur menjadi satu kesatuan, sehingga makna yang dimiliki dari seluruh kesatuan. Misalnnya kata membanting tulang, meja hijau. Sedangkan yang dimaksud dengan idiom sebagian adalah adalah idiom yang salah satu unsurnya masih memiliki makna leksikalnya sendiri, misalnya buku putih.

Sedangkan pribahasa makna yang dimiliki masih bisa ditelusuri atau dilacak makna unsur-unsurnya karena adanya asosiasi antara makna asli dengan maknanya sebagai pribahasa.

\section{Perkembangan dan Pergeseran makna}

Bentuk kebahasaan pada akhirnya dapat pula mengalami perkembangan, pergeseran, atau bahkan perubahan makna. Perkembangan, pergeseran, dan perubahan makna itu dapat terjadi secara:

Pertama, Meluas, yakni bila suatu bentuk kebahasaan mengalami berbagai penambahan makna yang keseluruhannya digunakan secara umum. Kata menarik yang semula berkaitan dengan tali, maknanya menjadi meluas sehingga dapat diartikan: cantik, cakap, simpatik, ganteng menyenangkan, baik. 
Kedua, Menyempit, yakni apabila makna suatu kata semakin memiliki spesifikasi atau spesialisasi. Kata guru, misalnya, pada mulanya bisa diartikan: pembimbing rohani, pengajar silat, dan akhirnya kata ini memiliki pengertian yang khusus yaitu pengajar di sekolah sebagai salah satu bidang profesi.

Disamping itu makna kata juga dapat mengalami pergerseran akibat adanya sikap dan penilaian tertentu masyarakat pemakainya, pergeseran itu berupa:

Pertama, Gradasi, yakni apabila makna suatu kata akhirnya dianggap memiliki nilai rendah atau memiliki konotasi negatif. Kata ngamar semula mengandung makna berada di kamar, tetapi akhirnya dapat mengandung pengertian negatif sehingga pemakaiannya pun berusaha dihindari.

Kedua, Elevasi, yakni bila suatu kata memiliki makna yang mana nilai maupun konotasi itu lebih baik dari makna sebelumnya. Seperti halnya kata wanita yang lebih dekat dengan bentuk betina dan betina akhirnya memiliki nilai lebih baik daripada kata perempuan.

Perlu diingat disini bahwa kata-kata yang dapat mengalami perkembangan, pergeseran, maupun perubahan makna umunya hanya terbatas pada bentuk kata yang mengandung makna penuh (full words). Sedangkan untuk bentuk kata yang memiliki makna setelah digabungkan dengan bentuk kata lainya, hanya mengalami peningkatan atau mungkin penurunan dalam frekwensi pemakain.

\section{Semantik/Makna dalam Al-Quran}

Kesadaran para sarjana (ulama) muslim untuk mempelajari dan mengkaji kitab Allah senantiasa berjalan secara berkesinambungan dari generasi ke generasi, kajian tersebut meliputi berbagai aspek sudut pandang, baik dari aspek teologi, politik, sosial dan tak luput pula kajian dari aspek bahasa dan sastra. Kajian Al-Qur'an dari aspek bahasa dan sastra utamanya kajian tentang makna (semantik) telah banyak menarik perhatian para sarjana klasik diantaranya "al-Asybh wa a; Nazhair fi Al-Qur'an Al-Karim oleh Muqatil ibn Sulaiman (150/767 H) 
yang kemudian dilanjutkan oleh Al-Jahiz (255/868H),Ibn Qutaibah (276/898H), dan Abdul Qohir Al-Jurjani (471/1079H), sejalan dengan Muqatil adalah Harun ibn Musa $(170 / 786 \mathrm{H})$ dalam Al-Wujuh wa AlNazhai'ir fi Al-Qur'an Al-Karim.

Salah satu hal yang disepakati dalam pelbagai aliran semantik dalam sprektrum linguistik modern adalah pembedaan antara makna dasar dan makna relasional. Makna dasar yang dimaksud disini adalah sebagaimana diungkapkan oleh Nur Kholis Setiawan (2005:166), bahwa kandungan kontekstual dari kosa kata yang akan tetap melekat pada kata tersebut, meskipun kata tersebut dipisahkan dari konteks pembicaraan kalimat. Dalam kasus Al-Quran, misalnya, kata kitab bisa dijadikan sebagai salah satu contoh makna dasar yang dalam pengertian pemakaian di dalam dan diluar Al-Qur'an artinya sama. Kandungan unsur semantik itu tetap ada pada kata tersebut dimanapun ia diletakkan dan bagaimanapun ia digunakan.

Sementara itu makna relasional adalah makna konotatif, yang dalam prakteknya sangat tergantung kepada konteks sekaligus relasi dengan kosa kata lainnya dalam kalimat. Kembali kepada contah kata kitab dalam makna dasar, ketika kita hubungkan dengan dengan katakata penting lain dalam Al-Qur'an semisal Allah,wahy, tanzil dan sebagainya akan mengalami pengembangan dan perluasan makna yang sangat berarti.

Muqatil ibn Sulaiman, sebagaimana dikutip dalam Nur Kholis Setiawan (2005:170), menegaskan bahwa setiap kata dalam Al-Qur'an, disamping memiliki arti yang definitif, juga memiliki beberapa alternatif makna lainnya. Salah satu contohnya adalah kata mawt, yang memiliki arti dasar mati. Menurutnya dalam konteks pembicaraan ayat, kata tersebut bisa memiliki 4 (empat) arti alternatif, yaitu: 1) Tetes yang belum dihidupkan, 2) Manusia yang salah beriman, 3) Tanah gersang dan tandus, 4) Ruh yang hilang. Dalam konteks surat Al-Zumar ayat 39 "Sesungguhnya kamu akan mati, juga mereka", kata tersebut berarti mati yang tidak bisa dihidupkan kembali. Berkenaan dengan kemungkinan makna yang dimiliki oleh kosa kata dalam Al-Qur'an, Muqatil 
menyatakan bahwa seseorang belum bisa dikatakan menguasai AlQur'an sebelum ia menyadari dan mengenal pelbagai demensi yang dimiliki Al-Qur'an tersebut.

Tentunya masih banyak contoh-contoh lain dari kosa kata tersebut, dan para sarjana (ulama) klasik menyebutkan kurang lebih ada delapan puluh kosa kata dalam Al-Qur'an yang mempuyai makna

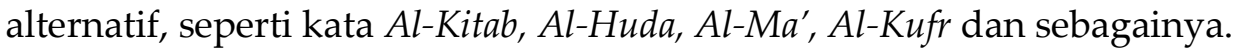

Aktivitas para sarjana (ulama') klasik berkenaan dengan "permainan" kosa kata dalam hubungannya dengan konteks, apalagi setelah dikaitkan perbincangan kosa kata Al-Qur'an, maka didapatkan hasil dan konklusi bahwa dalam Al-Qur'an, setidaknya terdapat tiga jenis kosa kata. Ketiga tersebut adalah pertama, kosa kata yang hanya memiliki satu makna, kedua, kosa kata yang memiliki dua alternatif makna dan ketiga, kosa kata yang memiliki banyak kemungkinan arti selaras dengan konteks dan struktur dalam kalimat yang memakainya (2005:177).

\section{Penutup}

Demikian pembahasan tentang makna kata, di mana para sarjana linguistik masih belum sepakat dengan sepenuh hati tentang banyak hal yang terkait dengan makna tentang apa itu makna, siapa yang berhak memberi makna, makna dan referensi, makna dan konsep, dan sebagainya. Namum demikian mereka sepakat bahwa satu kosa kata minimal mempunyai satu makna. Disamping itu makna kosa kata bisa mengalami perubahan sejalan dengan perubahan waktu, dan perubahan itu bukan merupakan persyaratan mutlak yang diperlakukan untuk setiap kata. Untuk menemukan makna yang dikehendaki oleh bahasa sumber untuk bahasa sasaran dalam proses menerjemah, maka harus melihat konteks situasi (Siyaq Al-Hal), konteks linguistik (Siyaq Al-Lughawy) dan konteks kultural (Siyaq Al-Tsaqofy).

Menerjemah suatu naskah bahasa sumber dan mencarikan padanan di dalam bahasa sasaran tidak semudah perkiraan kebanyakan orang. Menerjemah identik dengan mengkomunikasikan keterangan, 
pesan, atau gagasan yang ditulis oleh pengarang asli di dalam bahasa terjemahan. Oleh karenanya, makna memegang peranan penting dalam proses transfer/terjemah dari bahasa sumber ke bahasa sasaran sehingga seorang penerjemah benar-benar harus memperhatikan ketepatan (accuracy) makna mana yang cocok dengan apa yang dimaksudkan oleh penulis bahasa sumber untuk kemudian digunakan dalam bahasa sasaran. $\square$

\section{DAFTAR PUSTAKA}

Al-Khouli, M. Ali. 1982. Asalib Tadris Al-Lughoh Al-Arabiyah. Riyadh: Maktabah Al-Arabiyah Al-Saudiyah. 
Aminuddin. 2003. Semantik Pengantar Studi Tentang makna. Bandung: Sinar baru Algensindo.

Kridalaksana. 1982. Pengantar Linguistik Umum. Yogyakarta: Universitas Gajah Mada.

Muhammad, Anany. 2003. Nadhoriyah Al-Tarjamah Al-Haditsah, Madkhol Ila Mabahits Dirosah Al-Tarjamah. Mesir: Al-Syarikah Al-Misriyah Al-Alamiyah Li Al-Nasyr.

Newmark, Peter. 1981. Approaches to Translation. Oxford: Pergamon Press.

Nida, E.A. \& Charles R. Taber. 1969. The Teory and Practice of Translation. Leiden: E.J.Brill.

Rahardjo, Mudjia. 2005. Mengungkap Tabir di Balik Makna. Fakultas Humaniora dan Budaya UIN Malang.

Sapir. E. 1921. Language. Harcaourt: Brace and Warld.

Setiawan, M. Nur Kholis. 2005. Al-Qur'an Kitab Sastra Terbesar. Yogyakarta: Elsaq Press.

Toyib. 2005. Analisis Makna. Makalah disajikan dalam Seminar Nasional Menyingkap Tabir Makna di Balik Makna, Fakultas Humaniora dan Budaya UIN Malang.

Verhaar. J.W.M. 2001. Azas-Azas Linguistik Umum. Yogyakarta: Gajah Mada University Press.

Wahab, Abdul. 1995. Teori Semantik. Surabaya: Airlangga University Press.

Yusuf, Suhendra. 1994. Teori Terjemah Pengantar Ke arah Pendekatan linguistik dan Sosiolinguistik. Bandung: Mandar Maju. 